$\xi=$

\title{
The Effect of Puncture Load Cell Variation on Multi-Angle Layered Woven Fabric
}

\author{
N.A.A. Rahim, M.F. Yahya*, S.A. Ghani \\ Textile Research Group, Faculty of Applied Sciences, Universiti Teknologi MARA, 40450 Shah Alam, Selangor, Malaysia \\ *Corresponding author E-mail: mfy@salam.uitm.edu.my
}

\begin{abstract}
High tenacity polyester plain woven fabric punctured at multi angle layers were investigated. The main objective of the work was to analyse the effect of multi angle layered arrangement to quasi static puncture energy on different magnitude force. High tenacity polyester plain woven fabrics were weaved by using a rapier weaving machine at $300 \mathrm{rpm}$ and $100 \%$ efficiency. The woven fabric samples consisted of different angles $\left(90^{\circ}, 0^{\circ}, 45^{\circ}\right.$ and $\left.135^{\circ}\right)$. The maximum layers of woven fabric samples were two layers. The work was designed to evaluate the relationship between quasi static puncture energy of different load cell and multi angle layered of woven fabric. The results suggested that $10 \mathrm{kN}$ load cell gave the best value of puncture test and had been considered the appropriate force to test on woven fabrics.
\end{abstract}

Keywords: fabric layer, high tenacity polyester, impact energy, multi angle, plain woven

\section{Introduction}

Personal protective equipment is important in workplace to prevent injuries. Personal protective equipment consists of a range of clothing and equipment, which is to protect and to avoid workers form injuries while at work. Protective textile equipment especially in clothing used for protection against dangerous and harmful weapons [1]. Workers are responsible for wearing the personal protective equipment properly and use the necessary protection for their task. Body armor is the example of protective equipment widely used to protect from injuries. Body armor is not only used to defend wearer in opposition to bullets however also safety against sharp knives and spikes [2]. Other than military and arm forces, security officers are greatly exposed to ballistic and sharp objects while on duty. Therefore, protective equipment is mandatory to be used for security and protection industry workers.

Protective textile equipment generally made of composites or textile materials. This material based on the required application such as for helmets, shield, battle dress uniform and body armor [1]. It has been reported, composites are the most valuable structural materials in term of their utility, properties, adaptability and due to its high strength and stiffness [3] [4]. However, some applications such as ballistic protection vests, and gloves required flexible and soft texture. Soft armor protective equipment can be produced by using two distinctive fabric technology which are weaving and knitting processes. There are various types of textile fabric structure that can be used in protective textile such as knitted, braided, non-woven, and woven. Among all, woven fabrics has the most advantageous on the impact performance of protective textile. Several investigations have dealt with four factors on the effect of woven fabric structure when high speed impact is subjected. The factors are weaving architecture, yarn crimp, energy absorption and dissipation of fabric [5-9].

Plain weave structure is commonly used in woven fabric particularly for ballistic application. According to Trans et al, plain weave structures shows the highest strength but lower air permeability in comparison with twill and satin due to its compact structure [10]. This means, plain fabric reduces the slippage thus make it suitable for puncture resistance [2] [11]. However, there are problem on how yarns being interlaced with the stress concentration on impact due to the warp and weft position are at $90^{\circ}$. US National Institute Justice Body Armor stated a greater thickness of body armor which gives more protection to the wearer. Basically, when the layers are placed on top of each other all the stresses will be transferred at $0^{\circ}, 90^{\circ}, 180^{\circ}$ and $270^{\circ}$ angle. Yet, this presumed resulted low stress distribution especially at $45^{\circ}, 135^{\circ}, 225^{\circ}$ and $315^{\circ}$ angle. In order to give better view, the direction of angles is shown in Figure 1.

Poly-Para-Phenyleneterephthalamide is one of the examples of the fibres that commonly used for body armor. This fiber also known as kevlar. Kevlar is widely used for military application and by ordinary citizens especially in personal protective clothing and defense system and weapons [1]. Kevlar is specifically designed to withstand bullet and blade penetration. Generally, increasing the thickness of kevlar gives more protection to wearer. Besides, kevlar offer five-time higher tensile strength than steel and make kevlar is one of the strongest materials on earth. The essential characteristics make kevlar is one of highly demanded in the market, but they are bulky and inflexible to wearers [12-15]. Nevertheless, kevlar is expensive for civilian used in developing countries. Many researchers have focused on studies of soft body armour stab and puncture resistance, intense from fabric production $[2,11$, 16, 17] analytical model and FEM [18-22] as well as the shear fluid thickening (STF) behaviour [23-29]. These researches highlighted the importance of high modulus fibers for ballistic fabric manufacture. Carbon, glass and the ultra-high molecular weight polyethylene (UHMWPE) fibers are relatively expensive apart from Kevlar and always been used in improper application fields such as architecture and forestry, which the requirement for protection level is not so high [2]. There should be some other materials that can replace these costly fibers. Further research is there- 
fore worthwhile to use more economical materials, such as high tenacity polyester.

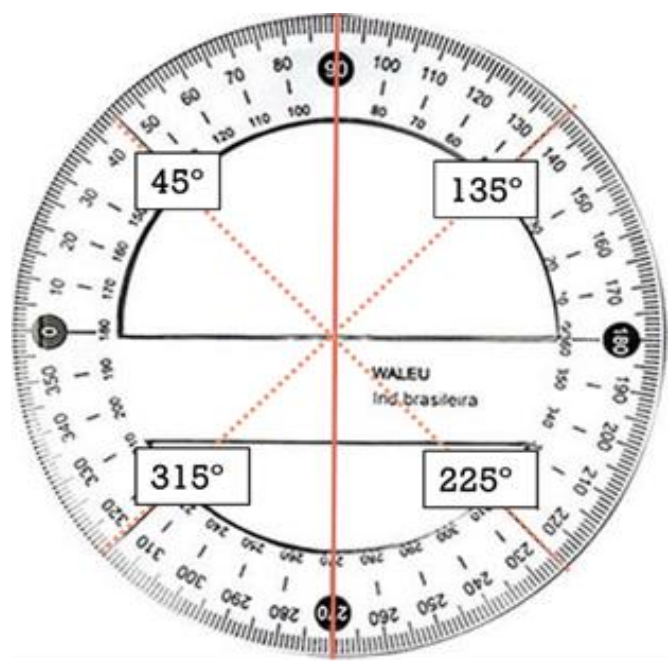

Fig 1: Angle of stress distribution

This experiment is prepared to investigate the feasibility of finding cost-effective materials for body amour through (i) studying single and multi-angle layered plain woven fabric, (ii) studying multiangle layered woven fabric for low puncture performance and (iii) puncture effect with different magnitude force.

\section{Materials and Method}

\subsection{Materials}

The high tenacity polyester yarns were used in the experimental study had tex count of 455 tex. The yarn was prepared with 8 number of yarns that plied to form single yarn by using hollow spindle ring spinning machine (YCHN-303) with $250 \mathrm{rpm}$. The single yarn strength was measured using SDL Testometric Strength Tester follow the guidelines of ASTM D2256 [30] and the tensile strength and elongation at break of the yarn were $293.64 \mathrm{~N}$ and $55.95 \mathrm{~mm}$ respectively.

The fabrics were manufactured by the jacquard rapier weaving machine (Donier PTS-8/JC) with $300 \mathrm{rpm}$ and $100 \%$ efficiency. High tenacity polyester yarns were used as weft yarns and polyester yarns used as warp yarns. The tex count of warp yarns was 150 tex. Plain is that the basic varieties of textile weaves. In plain weave, warp and weft yarns are aligned to make a pattern of interlacing. Each warp yarn crosses the weft yarn by passing over one, then below the following next weft yarn, etc.

The density of warp and weft was 32 ends per $\mathrm{cm}$ and 8 picks per $\mathrm{cm}$. The image of fabrics and weft yarns are shown in Figure 2 and Figure 3. Fabric samples has been tested in single and double layers. Table 1 present physical properties of woven fabric.

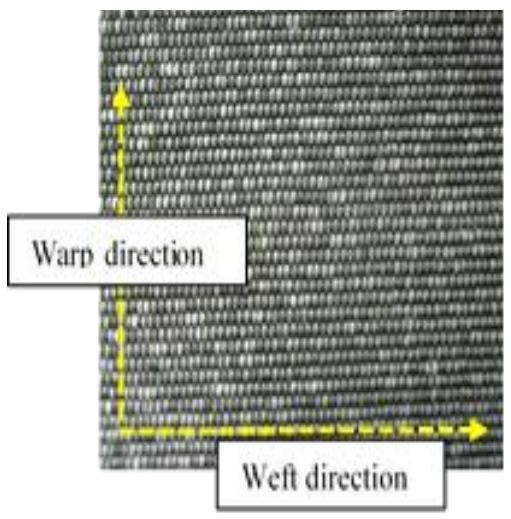

Fig 2: Plain woven fabric

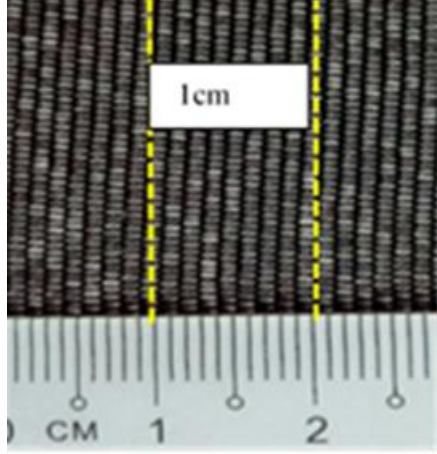

Fig 3: Weft density in one $\mathrm{cm}$

Table 1: Physical properties of woven fabric

\begin{tabular}{|c|c|c|c|}
\hline Fabric Type & Layer & Angle & Thickness (mm) \\
\hline $\begin{array}{c}\text { Plain weave } \\
\text { 32ends/cm and } \\
\text { 8picks/cm }\end{array}$ & 1 & $90^{\circ}$ & 0.81 \\
\cline { 2 - 4 } & \multirow{2}{*}{2} & $90^{\circ}, 90^{\circ}$ & 1.65 \\
\hline & & $90^{\circ}, 0^{\circ}$ & \\
\hline & & & 1.63 \\
\cline { 2 - 4 } & & $90^{\circ}, 45^{\circ}$ & 1.64 \\
\hline & & $90^{\circ}, 135^{\circ}$ & \\
\cline { 3 - 4 } & & & \\
\hline
\end{tabular}

\subsection{Fabric layering}

The fabrics were layered according to the angle of $90^{\circ}, 0^{\circ}, 45^{\circ}$ and $135^{\circ}$ as shown in Table 2.

Table 2: Fabric layer arrangement

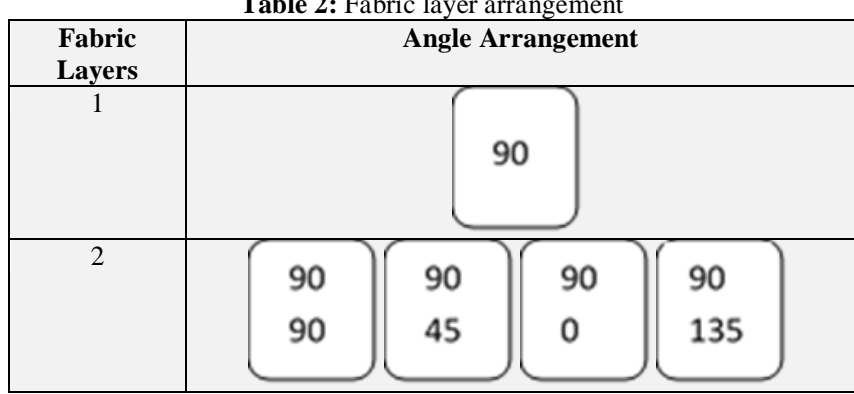

\subsection{Quasi Static Puncture Test}

Quasi static puncture test was measured using an impactor attached SDL Tensolab 3000 Mesdan machine and was developed in accordance with ASTM D5628 [31]. An impactor has been placed on the test tools shown in Figure 4. Figure 5 showed the photo-impactor used in the test. The shaft diameter was $25 \mathrm{~mm}$ the conical angle was $60^{\circ}$ and the impactor length was $50 \mathrm{~mm}$. the diameter of fabric samples is $130 \mathrm{~mm}$. the samples were placed in the centre between two circular plate with a diameter of $75 \mathrm{~mm}$ as shown in Figure 6. Load versus multi angle layered fabric were recorded and used for comparison of multi angle layered fabric performance. Five individual samples were measured in each of multi angle layered fabric.

The test is to estimate the low speed puncture resistance property on variations number of layers with different angle arrangement. The fabrics were punctured by two load cell force at $10 \mathrm{kN}$ and $50 \mathrm{kN}$. The height of both load cell reflects the different puncture force when the fabric has just penetrated the tip of the impactor. 


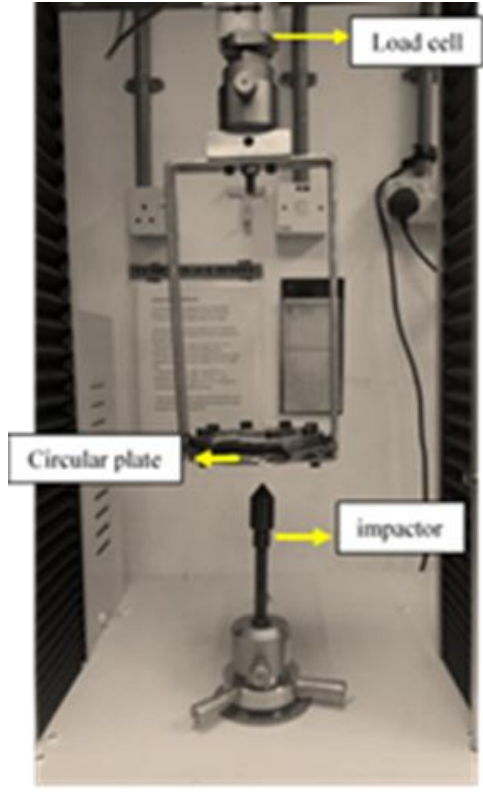

Fig 4: Quasi static puncture instrument

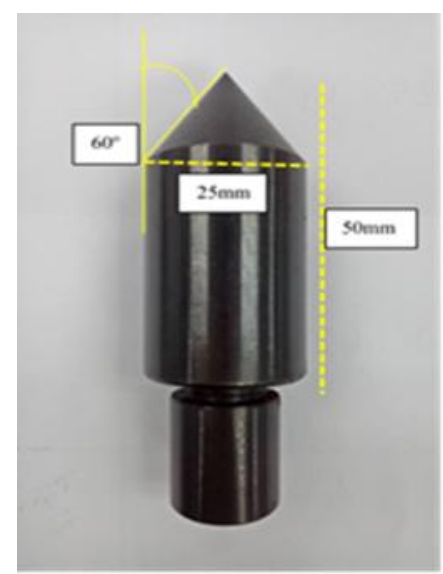

Fig 5: Impactor for the test

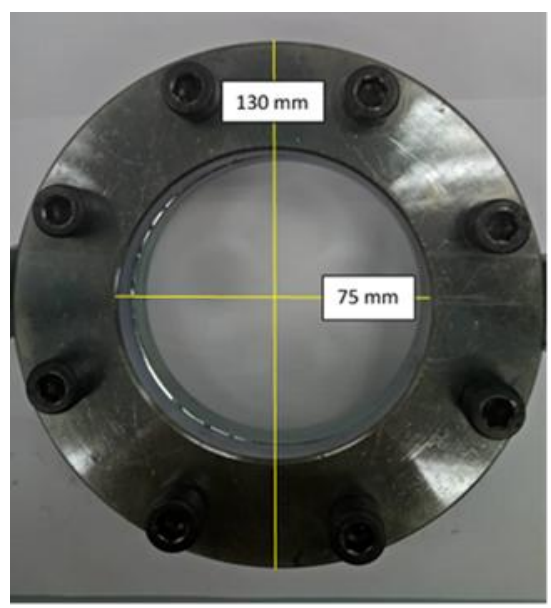

Fig 6: Circular plate

\subsection{The analysis of orders of magnitude (kilonewton)}

In the previous research, there is a huge magnitude force that can be applied to the fabric. The magnitude applied is specifically to test the strength of the fabric towards puncture performance. However, only several force that can be apply based on the application of the fabric. In order to describe the process more practically, the process is proposed on the basis of the change in the magnitude of puncture force. Table 3 shows the order of magni- tude force in kilonewton. In this study two load cell force at $10 \mathrm{kN}$ and $50 \mathrm{kN}$ were used.

\begin{tabular}{|c|c|c|}
\hline $\begin{array}{l}\text { Magnitude } \\
\text { kilonewton } \\
(\mathbf{k N})\end{array}$ & Value & Item \\
\hline \multirow[t]{2}{*}{$10^{3} \mathrm{~N}$} & $8 \mathrm{kN}$ & $\begin{array}{l}\text { The maximum force achieved by weight } \\
\text { lifters during "clean and jerk" lift }\end{array}$ \\
\hline & $9 \mathrm{kN}$ & The bite force of one adult American alligator \\
\hline \multirow[t]{4}{*}{$10^{4} \mathrm{~N}$} & $16.5 \mathrm{kN}$ & The bite force of a $5.2 \mathrm{~m}$ saltwater crocodile \\
\hline & $18 \mathrm{kN}$ & $\begin{array}{l}\text { The estimated bite force of } 6.1 \mathrm{~m} \text { adult great } \\
\text { white shark }\end{array}$ \\
\hline & $\begin{array}{l}25.5 \text { to } \\
34.5 \mathrm{kN}\end{array}$ & $\begin{array}{l}\text { The estimated bite force of a large } 6.7 \mathrm{~m} \text { adult } \\
\text { saltwater crocodile }\end{array}$ \\
\hline & $45 \mathrm{kN}$ & $\begin{array}{l}\text { The force applied by the engine of a small car } \\
\text { during peak acceleration }\end{array}$ \\
\hline \multirow[t]{2}{*}{$10^{5} \mathrm{~N}$} & $100 \mathrm{kN}$ & $\begin{array}{l}\text { The average force applied by seatbelt and } \\
\text { airbag to a restrained passenger in a car which } \\
\text { hits a stationary barrier at } 100 \mathrm{~km} / \mathrm{h}\end{array}$ \\
\hline & $890 \mathrm{kN}$ & $\begin{array}{l}\text { Maximum pulling force (tractive effort) of } \\
\text { single large diesel-electric locomotive }\end{array}$ \\
\hline
\end{tabular}

\section{Results and Discussions}

\subsection{Effect of number of layers}

Figure 7 outlines, as the number of layers increase the puncture resistance of fabric with different angle arrangement. As seen in Figure7, the maximum puncture force is positively correlated with the number of the layers of all angle arrangements. The puncture resistance of two layers of fabric is apparently better than that single layer. When number of layers reach two, the maximum puncture force for $50 \mathrm{kN}$ and $10 \mathrm{kN}$ increase $60 \%$ and $62 \%$ respectively.

High density fabric such as plain weave is expected to give lower absorption. It is therefore worth adding it with multilayer fabric.

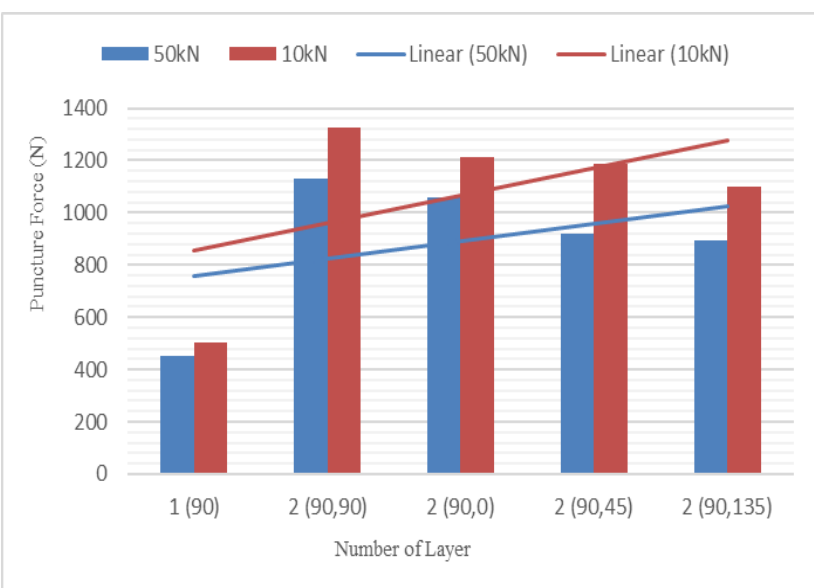

Fig 7: Maximum puncture force with different number of layer and different angle arrangement

It is an obvious linear relationship between the force of puncture and number of layers. However, the comparison angle arrangements of two layers of fabrics, it was found that 2 layers $\left[90^{\circ}, 90^{\circ}\right]$ had the highest value of puncture force that other. This indicates that the $\left[90^{\circ}, 90^{\circ}\right]$ angle arrangement perform better when layering the fabric. The maximum puncture force of the fabric for $10 \mathrm{kN}$ and $50 \mathrm{kN}$ was $1323.41 \mathrm{~N}$ and $1129.14 \mathrm{~N}$, higher than angle arrangement of $\left[90^{\circ}, 0^{\circ}\right],\left[90^{\circ}, 45^{\circ}\right]$ and $\left[90^{\circ}, 135^{\circ}\right]$.

\subsection{Effects of fabric structure and angle arrangement}

Plain fabric was used in the study. However, the direction of weft density was placed on different angle and this situation affect the results of puncture force. Figure 2 show the weft density of the 
plain fabric for the experimental study. Weft density at 8 picks per $\mathrm{cm}$ recorded the force reached the maximum value for $50 \mathrm{kN}$ and $10 \mathrm{kN}$ at $452.44 \mathrm{~N}$ and $505.14 \mathrm{~N}$ respectively.

Figure 7 shows the of the puncture force have been decreased. According to Wang et al [2], the puncture resistance property of the plain is better than other structure such as twill and satin. Therefore, the highest force value represents by the angle arrangement of $\left[90^{\circ}, 90^{\circ}\right]$.

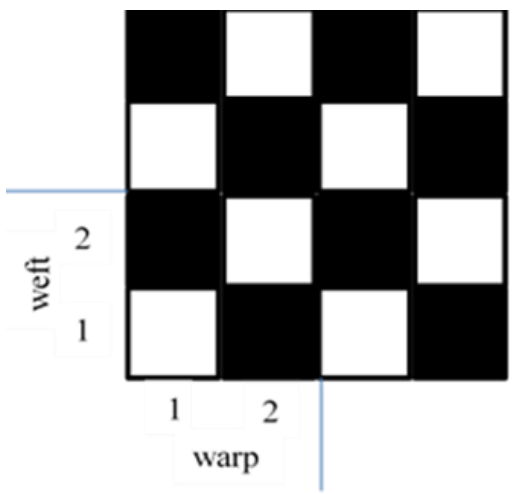

Fig 8: Plain weave notation

Figure 8 shows the plain structure that had normal angle value of $90^{\circ}$. The plain structure is tighter than the structures of twill and satin. The plain structure has more interlacing density of yarn [7]. The slippage of plain fabric is therefore less than that of other structures, so that the quasi static puncture resistance property of plain fabric is better than twill and satin structures [2] [11].

\subsection{Effect of puncture force on different load cell}

Two impact force were used in this study. The load cells were $10 \mathrm{kN}$ and $50 \mathrm{kN}$. Results from Figure 9 shows that the different force between $10 \mathrm{kN}$ and $50 \mathrm{kN}$ respectively. By using higher force, it shows the similar pattern with lower puncture force. From the results, $10 \mathrm{kN}$ was the possible load to apply on the fabric compared to $50 \mathrm{kN}$. Besides, the highest puncture force of $10 \mathrm{kN}$ increase about $194.27 \mathrm{~N}$ from $1129.14 \mathrm{~N}(50 \mathrm{kN})$. From Figure 9 can be concluded that $10 \mathrm{kN}$ was the suitable force to be apply on the experimental fabric compared to $50 \mathrm{kN}$.

$50 \mathrm{kN}$ not suitable for the study because the force given would be too high for a small sample. Table 3 has shown that $45 \mathrm{kN}$ is identical to force of engine peak acceleration. Due to availability factor, a load cell of $50 \mathrm{kN}$ was adopted in the study. On the other hand, the force magnitude of $10 \mathrm{kN}$ is closed to the bite force of alligator. The impact magnitude is suitable in the study since the woven fabric will be impacted with sharp impactor. Woven fabric designed for the work is expected to be used as hand gloves.

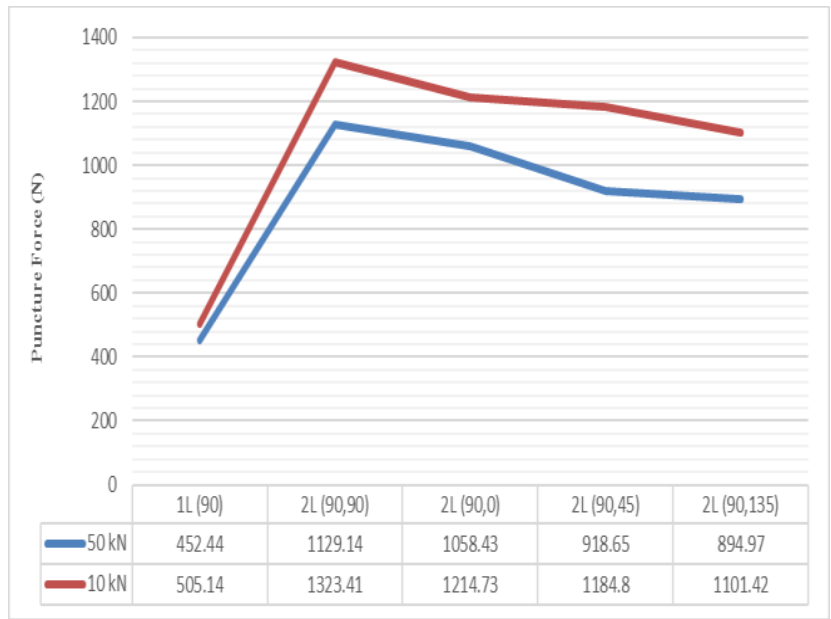

Fig 9: Maximum puncture force on different load cell

\section{Conclusion}

In all previous studies, relatively expensive high-performance fibers such as carbon, glass and ultra-high molecular weight polyethylene (UHMWPE) which are always used as manufacturing materials for puncture resistance. The obtained results from this study had laid an important platform from which to improve the puncture performance of high tenacity polyester weft direction of double layer fabrics. Puncture results of high tenacity polyester showed to have a better puncture performance. Polyester as mentioned earlier is more cost efficient than aramid and glass fiber. From this study, the puncture force values were enhanced when the multilayered woven fabric reached the optimal angle arrangement. On a two-layered fabric made of polyester, it was found that the puncture force value was improved at its optimal angle arrangement which was $\left[90^{\circ}, 90^{\circ}\right]$. The results also showed that $10 \mathrm{kN}$ load cell provided the suitable force to test on woven fabric which give the best values in of puncture tests. In conclusion, this study found that high tenacity polyester is not only an economic material but also possess a greater puncture resistance property as a multilayer fabric which can be used for many technical and engineering applications.

\section{References}

[1] Adanur, S. and A. Tewari, An overview of military textiles. 1997.

[2] Wang, Q.-S., et al., Quasi-static puncture resistance behaviors of high-strength polyester fabric for soft body armor. Results in physics, 2016. 6: p. 554-560.

[3] Padaki, N.V., et al., Low velocity impact behaviour of textile reinforced composites. Indian Journal of Fibre Br Textile Research, 2008.

[4] Demircan, O., et al., Effect of fiber densities on impact properties of biaxial warp-knitted textile composites. Journal of Reinforced Plastics and Composites, 2015. 34(16): p. 1287-1297.

[5] Cheeseman, B.A. and T.A. Bogetti, Ballistic impact into fabric and compliant composite laminates. Composite structures, 2003. 61(12): p. 161-173.1

[6] Tabiei, A. and G. Nilakantan, Ballistic impact of dry woven fabric composites: a review. Applied Mechanics Reviews, 2008. 61(1): p. 010801.

[7] El Messiry, M. and E. Eltahan, Stab resistance of triaxial woven fabrics for soft body armor. Journal of Industrial Textiles, 2016. 45(5): p. 1062-1082.

[8] Tan, V., V. Shim, and X. Zeng, Modelling crimp in woven fabrics subjected to ballistic impact. International journal of impact engineering, 2005. 32(1-4): p. 561-574.

[9] Roylance, D., Ballistics of transversely impacted fibers. Textile Research Journal, 1977. 47(10): p. 679-684.

[10] Tran, P., et al., Effects of architecture on ballistic resistance of textile fabrics: Numerical study. International journal of damage mechanics, 2014. 23(3): p. 359-376.

[11] Naik, N., S.N. Azad, and P.D. Prasad, Stress and failure analysis of 3D angle interlock woven composites. Journal of Composite Materials, 2002. 36(1): p. 93-123.

[12] Campbell Jr, F.C., Manufacturing processes for advanced composites. 2003: Elsevier.

[13] Chadwick, E., et al., Biomechanics of knife stab attacks. Forensic Science International, 1999. 105(1): p. 35-44.

[14] Davis, J.K. and B.J. Cates, Flame-resistant properties of aramid fibers. 1988, Google Patents.

[15] Netravali, A.N. and S. Chabba, Composites get greener. Materials today, 2003. 6(4): p. 22-29.

[16] Yang, C.-C., T. Ngo, and P. Tran, Influences of weaving architectures on the impact resistance of multi-layer fabrics. Materials \& Design, 2015. 85: p. 282-295.

[17] Yi, H. and X. Ding, Conventional approach on manufacturing 3D woven preforms used for composites. Journal of industrial textiles, 2004. 34(1): p. 39-50.

[18] Green, S., et al., Mechanical modelling of 3D woven composites considering realistic unit cell geometry. Composite Structures, 2014. 118: p. 284-293.

[19] Wang, P., B. Sun, and B. Gu, Comparison of stab behaviors of uncoated and coated woven fabrics from experimental and finite 
element analyses. Textile Research Journal, 2012. 82(13): p. 13371354 .

[20] Gu, B., Analytical modeling for the ballistic perforation of planar plain-woven fabric target by projectile. Composites Part B: Engineering, 2003. 34(4): p. 361-371.

[21] Rao, M., et al., Modeling the effects of yarn material properties and friction on the ballistic impact of a plain-weave fabric. Composite Structures, 2009. 89(4): p. 556-566.

[22] Sun, B., Y. Liu, and B. Gu, A unit cell approach of finite element calculation of ballistic impact damage of 3-D orthogonal woven composite. Composites Part B: Engineering, 2009. 40(6): p. 552560 .

[23] Decker, M., et al., Stab resistance of shear thickening fluid (STF) treated fabrics. Composites science and technology, 2007. 67(3-4): p. $565-578$.

[24] Kang, T.J., C.Y. Kim, and K.H. Hong, Rheological behavior of concentrated silica suspension and its application to soft armor. Journal of Applied Polymer Science, 2012. 124(2): p. 1534-1541.

[25] Mahfuz, H., et al., Enhanced stab resistance of armor composites with functionalized silica nanoparticles. Journal of Applied Physics, 2009. 105(6): p. 064307.

[26] Hassan, T.A., V.K. Rangari, and S. Jeelani, Synthesis, processing and characterization of shear thickening fluid (STF) impregnated fabric composites. Materials Science and Engineering: A, 2010. 527(12): p. 2892-2899.

[27] Kang, T.J., K.H. Hong, and M.R. Yoo, Preparation and properties of fumed silica/Kevlar composite fabrics for application of stab resistant material. Fibers and Polymers, 2010. 11(5): p. 719-724.

[28] Majumdar, A., B.S. Butola, and A. Srivastava, An analysis of deformation and energy absorption modes of shear thickening fluid treated Kevlar fabrics as soft body armour materials. Materials \& Design, 2013. 51: p. 148-153.

[29] Lu, Z., et al., Numerical simulation of the impact behaviors of shear thickening fluid impregnated warp-knitted spacer fabric. Composites Part B: Engineering, 2015. 69: p. 191-200.

[30] Nor, S.M. and A.G. Suzaini, A Manual on Textile Testing. 2012, Selangor: Penerbit Press Universiti Teknologi MARA.

[31] Hassan, M., S. Naderi, and A. Bushroa, Low-velocity impact damage of woven fabric composites: Finite element simulation and experimental verification. Materials \& Design, 2014. 53: p. 706718.

[32] Weinstein, L. and J.A. Adam, Guesstimation: Solving the world's problems on the back of a cocktail napkin. Am. J. Phys, 2008. 76: p. 887.

[33] Erickson, G.M., A.K. Lappin, and K.A. Vliet, The ontogeny of biteforce performance in American alligator (Alligator mississippiensis). Journal of Zoology, 2003. 260(3): p. 317-327. 